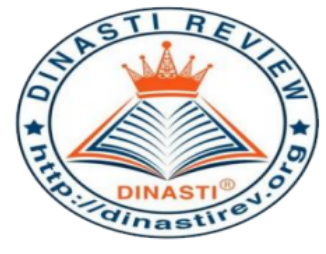

+62 878-9658-6407

087896586407

https://dinastirev.org/JIMT

editor@dinastirev.org

\title{
ANALISIS POTENSI DAN STRATEGI PENGELOLAAN EKOWISATA DI KAWASAN HULU AIR LEMPUR KABUPATEN KERINCI JAMBI
}

\author{
Muhammad Syafrii ${ }^{1)}$, Albayudi' ${ }^{2)}$ \\ ${ }^{1)}$ Dosen FEB Universitas Jambi \\ ${ }^{2)}$ Mahasiswa Program Studi Ilmu Lingkungan Universitas Jambi
}

\begin{tabular}{|c|c|}
\hline $\begin{array}{l}\text { ARTICLE INFORMATION } \\
\text { Received: } 15 \text { April } 2020 \\
\text { Revised: } 20 \text { April } 2020 \\
\text { Issued: } 26 \text { April } 2020 \\
\text { Corresponding Author: } \\
\text { Muhammad Syafri } \\
\text { E-mail: m_syafri@unja.ac.id } \\
\text { yudia.bch@gmail.com }\end{array}$ & $\begin{array}{l}\text { Abstrak: Salah satu sumberdaya alam di Provinsi Jambi } \\
\text { tersebut terletak di Kabupaten Kerinci, Kecamatan Gunung } \\
\text { Raya tepatnya di kawasan Hulu Air Lempur, wisatawan } \\
\text { mengenalnya sebagai desa wisata Lempur. Penelitian ini } \\
\text { bertujuan: 1) Menghitung potensi keanekaragaman } \\
\text { sumberdaya ekowisata alam, 2) Menganalisis peranan } \\
\text { sumberdaya manusia pada aspek ekonomi dan sosial budaya } \\
\text { 3) Menghitung Nilai Willingness to Pay berdasarkan harga } \\
\text { tiket masuk melalui pendekatan Contingent Valuation } \\
\text { Method, 4) Menganalisis strategi pengelolaan ekowisata } \\
\text { ekowisata di Kawasan Hulu Air Lempur, Kabupaten Kerinci. } \\
\text { Berdasarkan hasil skoring peranan sumberdaya alam pada } \\
\text { bidang Objek ekowisata di Hulu Air Lempur adalah sangat } \\
\text { layak untuk dikembangkan menurut prioritas secara berurutan } \\
\text { sebagai berikut: Danau Kaco, Danau Duo, Danau Nyalo, } \\
\text { Panorama Alam Bukit Kemulau, Danau Kecik, air terjun } \\
\text { Seluang Bersisik Emas dan Danau Lingkat. Peranan aspek } \\
\text { sosial dan ekonomi memberikan distribusi yang sangat } \\
\text { beragam dan signifikan baik terhadap kondisi dan minat } \\
\text { wisatawan maupun terhadap kontribusinya bagi masyarakat } \\
\text { setempat. Hasil analisis regresi berganda bahwa variabel usia } \\
\text { berpengaruh secara signifikan pada tarap } 5 \% \text {. Pada analisis } \\
\text { Willingness to Pay melalui metode Contingent Valuation } \\
\text { Method menunjukan bahwa pengunjung ekowisata bersedia } \\
\text { membayar pengganti tiket sebesar Rp 11.000. Pada Analisis } \\
\text { SWOT menunjukkan bahwa posisi titik potong diagram (0,80 } \\
\text {; 0,40), yaitu berada pada posisi kuadran I, artinya } \\
\text { peningkatan pengelolaan ekowisata secara komprehensif, } \\
\text { berbasiskan lingkungan harus didukung secara multisektoral } \\
\text { terutama masyarakat setempat dengan menggalakan bidang } \\
\text { promosi dan publikasi objek ekowisata secara nasional } \\
\text { bahkan ketingkat Internasional. } \\
\text { Kata Kunci: Potensi, Sumberdaya Alam, Peranan Sosial } \\
\text { ekonomi, Pengelolaan Ekowisata. }\end{array}$ \\
\hline
\end{tabular}




\section{PENDAHULUAN \\ Latar Belakang}

Jambi merupakan salah satu provinsi yang memiliki kekayaan sumberdaya alam khususnya dari sektor kehutanan dan pariwisata alam atau ekowisata. Salah satu sumberdaya alam di Provinsi Jambi terletak di Kabupaten Kerinci Kecamatan Gunung Raya tepatnya di Kawasan tiga desa yaitu, Desa Lempur Mudik, Desa Lempur Tengah dan DesaLempur Hilir.Banyak kalangan mengenalnya dengan sebutan desa wisata Lempur. Kemudian kawasan ini juga termasuk pada wilayah Hulu Air Lempur dengan banyak keunikan destinasi ekowisata, yaitu Danau Lingkat, Danau Kecik, Danau Duo, Danau Nyalo dan Air Terjun Seluang Bersisik Emas (Disporaparbud Kabupaten Kerinci, 2010).

Potensi ekowisata alam yang ada di Desa Lempur memiliki potensi obyek dan daya tarik ekowisata/ wisata alam (ODTWAdan tidak hanya terdapat dalam Kawasan Hulu Air Lempur saja, namun terdapat pula potensi wisata alam di luar Kawasan Hulu Air Lempur sepertiDanau Kaco yang berada dalam kawasan Taman Nasional Kerinci Seblat yang berbatasan langsung dengan kawasan Hutan Adat Gunung Batuah. Desa wisata Lempur tidak hanya memiliki keindahan panorama alam, namun masyarakat di kawasan ini juga memiliki kekayaan budaya, adat istiadat dan peninggalan sejarah seperti Benteng Depati Parbo, Batu Meriam, Batu Kursi, Batu Bersurat dan beberapa Masjid Kuno(Disporaparbud Kabupaten Kerinci, 2010).

Pada tahun 2015 yang lalu Presiden Republik Indonesia menganugerahkan kepada Lembaga Adat Lekuk 50 Tumbi sebuah penghargaan tertinggi dibidang lingkungan, yaitu KALPATARU, dengan pertimbangan bahwa masyarakat adat di kawasan Lempur telah mampu menjaga kawasan hutan adat seluas 40.000 hektar dengan baik (Kalpataru, Posted 2016).Konsep pengembangan Ekowisata yang diemban kawasan Lekuk 50 Tumbi ini bukanlah pekerjaan mudah, sehingga perlu adanya pengkajian secara detail, apalagi menurut Iqoni, N (2016)dalam http://www.kerincitoday.com/2016, bahwa kawasan wisata yang ada di Kabupaten Kerinci terutama kawasan Lempur harus ditata dan dikelola secara serius disaat kondisi sumberdaya alam mengalami penurunan.

\section{Rumusan Masalah}

Berdasarkan hal tersebut, maka dalam penelitian ini telah di rumuskan masalah yang dikemukan adalah sebagai berikut : 1) Seberapa besar nilai potensi keanekaragaman sumberdaya alam yang ada di Kawasan Hulu Air Lempur 2) Seberapa besarperanan sumberdaya manusia melaui aspek ekonomi dan sosial budaya di kawasan Hulu Air Lempur, 3) Seberapa besar nilai Willingness to pay berdasarkan harga tiket masuk dengan pendekatan Metode Valuasi Kontingensi, pada kawasan ekowisata Hulu Air Lempur, 4) Bagaimana bentukrancangan untuk strategi pengembanganserta pengelolaan ekowisata alam berbasis konservasi alam di Kawasan Hulu Air Lempur. Kabupaten Kerinci

\section{Tujuan Penelitian}

Adapun tujuan dari penelitian mengenai Analisis Potensi Sumberdaya Alam Dan Strategi Pengelolaan EkowisataDi Kawasan Hulu AirLempur Kabupaten KerinciKabupaten Kerinciadalah: 1) Menghitung potensi keanekaragaman sumberdaya ekowisata alam yang ada di Kawasan Hulu Air Lempur, 2) Menganalisis peranan sumberdaya manusia pada aspek ekonomi dan sosial budaya di kawasan Hulu Air Lempur, 3) Menghitung Nilai Willingness to pay berdasarkan harga tiket masuk melaluipendekatan Metode Valuasi Kontingensi atau Contingent Value Method (CVM) ekowisata Hulu Air Lempur, 4) Menganalisis rancangan untuk pengembangan serta perlindungan ekowisata berbasis konservasi sumberdaya alam di Kawasan Hulu Air Lempur, Kabupaten Kerinci. 


\section{METODE PENELITIAN}

Penelitian ini bersifat deskriptif kuantitaif. Metoda yang mendeskripsikan atau menggambarkanfenomena yang diteliti secara sistematis dan akurat (Natsir, 1998). Penelitian ini bertujuan untuk menggambarkan dengan lebih baik sifat-sifat yang relevan dengan variable-variabel yang diteliti. Populasi penelitian ini adalah para wisatawan yang berkenjung kekawasan Hulu Air Lempur, masyarakat biasa dan masyarakat adat yang berada di sekitar lokasi ekowisata tersebut termasuk para pelaku bisnis pariwisata, pencinta alam dan unsurunsur pemerintahan.

Penelitian ini dilaksanakan pada bulan Juli 2017 sampai dengan bulan September 2017 di Kawasan Hulu Air Lempur, Kecamtan Gunung Raya Kabupaten Kerinci.Adapun teknik untuk pengambilan sampel dilakukan dengan cara purposive sampling, yaitu dilakukan dengan sengaja untuk menentukan baik tempat maupun responden yang akan diwawancarai dan di berikan kuesioner pada mereka Arikunto (2006) .

\section{Metode Analisis Penelitian Metode Skoring}

Data mengenai potensi obyek dan daya tarik wisata alam diolah dengan menggunakan pedoman ADO-ODTWA Dirjen PHKA tahun 2003 yang telah dimodifikasi.Modifikasi dilakukan terhadap sub unsur untuk menyesuaikan dengan kondisi obyek wisata alam yang dinilai. Bobot setiap obyek wisata digunakan untuk menentukan skor/nilai setiap obyek wisata berdasarkan enam kriteria penilaian, yaitu daya tarik wisata, aksesibilitas, kondisi lingkungan sosial ekonomi (radius jarak dari batas kawasan intensive useatau jarak terdekat dengan obyek), akomodasi (radius $5 \mathrm{~km}$ dari obyek),sarana prasarana penunjang, dan kriteria penilaian ketersediaan air bersih. Jumlah nilai untuk satu kriteria penilaian ODTWA dapat dihitung dengan menggunakan persamaan:

\section{$\mathbf{S}=\mathbf{N} \mathbf{X} \mathbf{B}$}

Keterangan: $\quad \mathrm{S}=$ skor/nilai suatu kriteria

$\mathrm{N}=$ jumlah nilai unsur-unsur pada kriteria

$\mathrm{B}=$ bobot nilai

\section{Analisis Peran}

Untuk mengetahui peran stake holder seperti peranan lembaga adat Lekuk 50 Tumbi, pemerintah derah setempat, lembaga-lembaga yang konsentrasi dengan ekowisata dikawasan Hulu Air Lempur, maka digunakan analisis persentase berikut ini :

$$
\begin{aligned}
& \mathrm{P}=\frac{\sum \mathrm{F}}{\sum \mathrm{N}} \times 100 \% \\
& \mathrm{P}=\text { Persentase }
\end{aligned}
$$

$\sum \mathrm{F}=$ Jumlah Frekwensi yang muncul

$\sum \mathrm{N}=$ Jumlah keseluiruhan responden 
Hasil pengukuran peranan selanjutnya dianalisis dengan mengkategorikan seperti Tabel berikut ini :

Tabel 1. Kategori Tingkat Peran untuk Setiap Stake Holders

\begin{tabular}{|l|c|c|}
\hline No & Persentase & Kreteria \\
\hline $\mathbf{1}$ & $89-100$ & Sangat Tinggi \\
\hline $\mathbf{2}$ & $61-88$ & Tinggi \\
\hline $\mathbf{3}$ & $41-60$ & Sedang \\
\hline $\mathbf{4}$ & $12-40$ & Rendah \\
\hline $\mathbf{5}$ & $<12$ & Sangat Rendah \\
\hline
\end{tabular}

Sumber : Gulo, W, 2012

AnalisisBiaya Perjalanan (Travel Cost Method)untuk Memperoleh Nilai Ekonomi Kawasan Hulu Air Lempur Kabupaten Kerinci

Pengelolaan sumber daya alam Kawasan Ekowisata Hulu Air Lempur Kabupaten Kerinci dapat ditinjau sebagai barang publik, yang mempunyai berbagai daya tarik alami, maka perlu dilakukan tindakan dan perlakuan terencana karena pengembangan kawasan wisata dapat memicu tumbuhnya dampak positif dan negatif, baik terhadap ekonomi dan sosial budaya maupun kelestarian sumberdaya alamnya. Untuk mendapatkan nilai (value) yang hasilnya dapat dimanfaatkan oleh banyak pihak terutama masyarakat disekitar kawasan Hulu Air Lempur, maka dibuatlah satu pola kalkulasi nilai ekonomi wisata.

\section{Analisis Willingness To Pay dengan Pendekatan Metode Valuasi Kontingensi atau Contingent Valuation Method (CVM)}

Metode Valuasi Kontingensi atau Contingent Valuation Method (CVM) merupakan metode valuasi sumber daya alam dan lingkungan dengan cara menanyakan secara langsung kepada konsumen (Nasir, 2009). Tahapan yang dilakukan Menurut Fauzi (2010) antara lain mengetahui : Jumlah WTP, Memperkirakan kurva Willingness to Pay (WTP), yang berfungsi sebagai variabel dipenden dan faktor-faktor yang mempengaruhi nilai-nilai tersebut.

Menganalisis CVM (Contingen Valuation Method) dengan kemauan membayar responden di kawasan Hulu Air Lempur yang dipengaruhi oleh variabel-variabel seperti : pendapatan, pendidikan, usia serta sarana dan prasarana. Kemudian langkah berikutnya membuat formulasi sebagai berikut :

\section{$\operatorname{Ln} \operatorname{WTP}(Y)=\mathbf{f}\left(\operatorname{Ln} X_{1}, X_{2}, \operatorname{LnX} X_{3}, X_{4}\right)$}

Keterangan :

Ln WTP $(\mathrm{Y}) \quad=$ Willingness To Pay/ Ketersediaan membayar

$\mathrm{LnX}_{1} \quad=$ Pendapatan

$\mathrm{X}_{2} \quad=$ Pendidikan

$\mathrm{LnX}_{3} \quad=$ Usia

$\mathrm{X}_{4} \quad=$ Sarana dan Prasarana

Dari formulasi diatas untuk memperoleh arah hubungan antara variabel independen dan variabel dependen, maka digunakanlah analisis regresi linear berganda melalui pembobotan menggunakan SPSS (Statistical Package for the Social Science), yaitu sebagai berikut :

$\operatorname{LN~WTP~}(\mathrm{Y})=\beta_{0}+\beta_{1} \operatorname{LnX} X_{1}+\beta_{2} X_{2}+\beta_{3} \operatorname{LnX}_{3}+\beta_{4} X_{4}+\varepsilon_{t}$

Keterangan :

Ln WTP $(\mathrm{Y}) \quad$ = Willingness To Pay/ Ketersediaan membayar 


$\begin{array}{ll}\beta_{0} & =\text { Intersep/ Konstanta } \\ \beta_{1}, \beta_{2}, \beta_{3}, \beta_{4} & =\text { Koefisien regresi } \\ \operatorname{LnX} & =\text { Pendapatan } \\ \mathrm{X}_{2} & =\text { Pendidikan } \\ \operatorname{LnX}_{3} & =\text { Usia } \\ \mathrm{X}_{4} & =\text { Sarana dan Prasarana }\end{array}$

\section{Analisis Pola Perancangan Strategis Kawasan Ekowisata Hulu Air Lempur}

Analisis pola perancangan menggunakan analisis SWOT yaitu instrumen yang digunakan untuk melakukan analisis strategis. Menurut Simbolon, R (1999) dalam Hery Yana (2015), analisis SWOT merupakan suatu alat yang efektif dalam membantu menstrukturisasikan masalah, terutama dengan melakukan analisis atas lingkungan strategis, yang lazim disebut sebagai lingkungan internal dan lingkungan eksternal di kawasan Ekowisata Hulu Air Lempur, Kabupaten Kerinci dan juga diuraikan secaradeskriptif dan menentukan obyek prioritas yang berpotensi untukdikembangkan.

\section{Matriks SWOT}

Matriks SWOT alat yang akan digunakan untuk menyususn faktor-faktor strategis dalam membuat rancangan untuk perlindungan dan pengelolaan ekowisata dikawasan hulu air lempur, Kabupaten Kerinci. Matriks ini dapat menggambarkan secara jelas bagaimana peluang dan ancaman eksternal pada kondisi saat ini dan juga dapat disesuaikan dengan faktor-faktor kekuatan dan kelemahan yang dimilikinya. Matriks ini dapat menghasilkan empat (4) set kemungkinan alternatif strategis, seperti pada diagram 1, berikut ini :

Tabel 2. Matriks SWOT

\begin{tabular}{|c|c|c|}
\hline EFAS & $\begin{array}{l}\text { STRENGTHS (S) } \\
\text { - Menentukan faktor-faktor } \\
\text { yang memiliki kekuatan } \\
\text { internal }\end{array}$ & $\begin{array}{l}\text { WEAAKNESSES }(\mathrm{W}) \\
\text { - Menentukan faktor-faktor } \\
\text { yang memiliki kelemahan } \\
\text { internal }\end{array}$ \\
\hline $\begin{array}{l}\text { OPPORTUNES }(\mathrm{O}) \\
\text { - Menentukan faktor-faktor } \\
\text { yang memiliki peluang } \\
\text { eksternal }\end{array}$ & 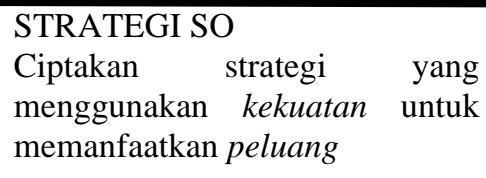 & $\begin{array}{l}\text { STRATEGI WO } \\
\text { Ciptakan strategi yang } \\
\text { meminimalkan kelemahan } \\
\text { untuk memanfaatkan peluang }\end{array}$ \\
\hline $\begin{array}{l}\text { TREATHS (T) } \\
\text { - Menentukan faktor-faktor } \\
\text { yang memiliki ancaman } \\
\text { eksternal }\end{array}$ & \begin{tabular}{l}
\multicolumn{2}{l}{ STRATEGI ST } \\
Ciptakan strategi yang \\
menggunakan kekuatan untuk \\
mengatasi ancaman
\end{tabular} & $\begin{array}{l}\text { STRATEGI WT } \\
\text { Ciptakan strategi yang } \\
\text { meminimalkan kelamahan dan } \\
\text { menghindari } \text { ancaman }\end{array}$ \\
\hline
\end{tabular}

Sumber : Rangkuti, F, 2005

\section{Matriks Space}

Selanjutnya setelah didapat internal - eksternal strategic factor analysis summary ( IFAS - EFAS), guna mempertajam strategi tersebut dibuatlah Matriks Space dalam rangka menganalisa Strategi pada pengelolaan ekowisata di Kawasan Hulu Air Lempur, Kabupaten Kerinci. Berikut ini adalah gambaran untuk Gambar Matriks Space dari penelitian ini. 


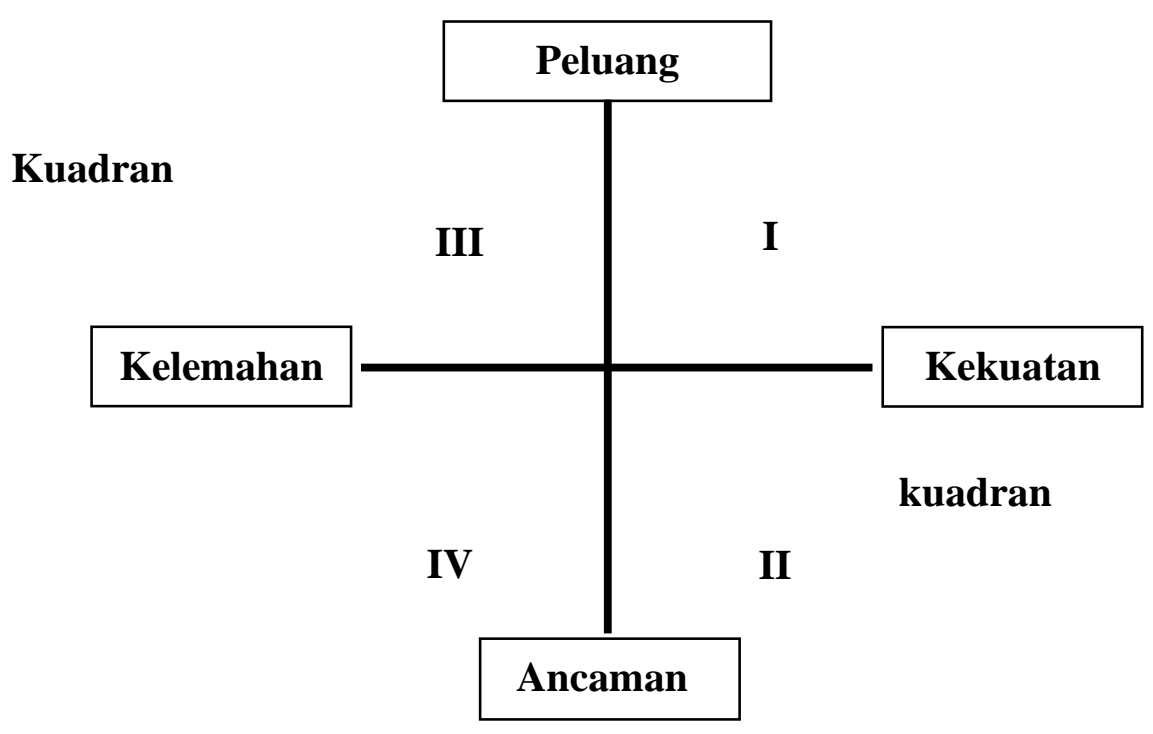

Gambar 1. Matriks Space untuk Grand Strategi Penelitian

\section{HASIL DAN PEMBAHASAN}

\section{Kondisi Umum Kawasan Hulu Air Lempur Kecamatan Gunung Raya Kabupaten Kerinci}

Secara administratif pemerintahan, wilayah Hulu Air Lempur terletak di Kecamatan Gunung Raya, di sebelah barat laut berbatasan dengan Kecamatan Danau Kerinci, ke arah Tenggara berbatasan dengan Kecamatan Jangkat Kabupaten Merangin. Hutan Adat di daerah Hulu Air Lempur (yang dikenal dengan Hutan Hak Adat Lempur) termasuk dalam wilayah lingkungan Adat Lekuk 50 Tumbi Lempur dengan luas 858,3 ha. Pengelolaan Hutan Adat Lempur dilakukan oleh Perwalian Masyarakat Adat Desa Lembaga Kerja Tetap Daerah Hulu Air Lempur.

\section{Penilaian Objek dan Daya Tarik Wisata Alam (ODTWA) Pada Kawasan Hulu AirLempur Kriteria Penilaian ODTWA}

Kriteria penilaian objek dan daya tarik wisata alam merupakan suatu instrumen untuk mendapatkan kepastian kelayakan suatu objek untuk dikembangkan sebagai objek wisata. Fungsi dari kriteria adalah sebagai dasar dalam pengembangan objek dan daya tarik wisata melalui penetapan unsur kriteria, penetapan bobot, perhitungan masing-masing sub unsur dan penjumlahan dari semua kriteria (Dirjen PHKA, 2003). Kriteria penilaian dilakukan terhadap daya tarik, aksesibilitas, kondisi lingkungan sosial ekonomi, akomodasi, sarana-prasarana penunjang dan ketersediaan air bersih. Penilaian kriteria dilakukan pada obyek-obyek wisata yang berpotensi untuk dikembangkan. Hasil pengamatan terhadap potensi-potensi di Kawasan Hulu Air Lempur. 
Tabel 3. Rekapitulasi Penilaian ODTWA

\begin{tabular}{|l|c|c|c|c|c|c|c|}
\hline \multicolumn{1}{|c|}{$\begin{array}{c}\text { Kriteria } \\
\text { Penilaian }\end{array}$} & \multicolumn{2}{|c|}{ Obyek Wisata Alam } \\
\hline Lingkat & $\begin{array}{c}\text { Danau } \\
\text { Duo }\end{array}$ & $\begin{array}{c}\text { Danau } \\
\text { Kecik }\end{array}$ & $\begin{array}{c}\text { Danau } \\
\text { Nyalo }\end{array}$ & $\begin{array}{c}\text { Danau } \\
\text { Kaco }\end{array}$ & $\begin{array}{c}\text { Air Terjun } \\
\text { Seluang Bersisik } \\
\text { Emas }\end{array}$ & $\begin{array}{c}\text { Panorama } \\
\text { Alam Bukit } \\
\text { Kemulau }\end{array}$ \\
\hline Daya tarik & 1080 & 1080 & 1080 & 1080 & 1170 & 1140 & 1080 \\
\hline Aksesibilitas & 550 & 725 & 700 & 725 & 750 & 575 & 725 \\
\hline $\begin{array}{l}\text { Kondisi } \\
\text { lingkungan } \\
\text { sosial ekonomi }\end{array}$ & 525 & 525 & 525 & 525 & 530 & 525 & 525 \\
\hline Akomodasi & 150 & 150 & 150 & 150 & 150 & 150 & 150 \\
\hline $\begin{array}{l}\text { Sarana } \\
\text { prasarana } \\
\text { penunjang }\end{array}$ & 240 & 240 & 240 & 240 & 240 & 240 & 240 \\
\hline $\begin{array}{l}\text { Ketersediaan } \\
\text { air bersih }\end{array}$ & 870 & 870 & 870 & 870 & 870 & 870 & 870 \\
\hline \multicolumn{1}{|c|}{ Jumlah } & $\mathbf{3 4 1 5}$ & $\mathbf{3 5 9 0}$ & $\mathbf{3 5 6 5}$ & $\mathbf{3 5 9 0}$ & $\mathbf{3 7 1 0}$ & $\mathbf{3 5 0 0}$ & $\mathbf{3 5 9 0}$ \\
\hline
\end{tabular}

Sumber : Hasil Analisis dan Perhitungan berdasarkan Pedoman Dirjen PHKA, 2003

Berdasarkan Tabel 3 dapat dilihat bahwa objek ekowisata Danau Kaco memiliki skor tertinggi daripada tempat ekowisata lainnya, yaitu 3710, artinya sangat layak untuk dikembangkan dan menjadi pilihan utama wisatawan yang ingin bertualang dengan beberapa kreteria penilaian meliputi : daya tarik, aksesibilitas, lingkungan sosial ekonomi, akomodasi, sarana dan prasarana, serta ketersediaan air. Peringkat berikutnya adalah danau Duo, Danau Nyalo dan Panorama Alam Bukit Kemulau, skornya masing-masing 3590. Kemudian disusul oleh Danau Kecik (3565), Air Terjun Seluang Bersisik Emas (3500) dan Danau Lingkat (3415), dari hasil rekapitulasi penilaian ODTWA dapat ditentukan objek wisata alam yang menjadi objek prioritas untuk dikembangkan sebagai objek wisata di Kawasan Hulu Air Lempur yaitu Danau Duo, Danau Nyalo dan Panorama Alam Bukit Kemulau. Objek ekowisata lain yang nilainya terendah adalah Danau Lingkat yaitu 3415. Kecilnya skor yang diperoleh danau Lingkat bukan berarti tidak menjadi pilihan wisatawan, justru yang paling ramai dikunjungi adalah danau Lingkat, akan tetapi menurut Dirjen PHKA, 2003, tidak memiliki tantangan sebagai wisata petualangan. Karena lokasinya sangat mudah dijangkau dan akses ke danau Lingkat lebih terjangkau, hingga para wisatawan lebih memilih Danau Kaco untuk menguji kemampuan wisatawan, dengan melawati banyak tantangan serta ke unikan-keunikan lainnya. Begitu juga dengan Danau Duo, Danau Nyalo serta panorama bukit Kemulau kemungkinan untuk dilakukan pengembangan ekowisata dan dimasukkan dalam rencana pengembangan parwisata alam di Kawasan Hulu Air Lempur.

\section{Peranan Aspek Sosial dan Ekonomi Pengunjung pada Kawasan Ekowisata Hulu Air Lempur}

Pada prinsipnya penilaian peran dapat dilihat dari dua aspek, yaitu aspek ekonomi dan aspek sosial. Data-data diambil dari hasil quesioner responden yang ada dan berkunjung di kawasan ekowisata. Dalam penelitian ini kesemua aspek tersebut mencakup variabel-variabel yang mempengaruhi tingkat kunjungan ke daerah Ekowisata Kawasan. Dari variabel-variabel tersebut di atas diambil beberapa karakteristik yang dapat dijadikan tolok ukur untuk menentukan peranan aktivitas pendukung kawasan ekowisata Hulu Air Lempur.Responden yang menjadi obyek penelitian adalah pengunjung yang telah selesai melakukan kunjungan kawasan ekowisata Hulu Air Lempur.Peranan Aspek Sosial mencakup : a) pendidikan yang 
berperanan menonjol adalah tingkat SMA $46 \%$ dan S1 48\%, b) Usia yang berperanan menonjol adalah usia 15 sampai 26 tahun sebesar $70 \%$ dan c) Jenis Kelamin yang berperanan menonjol adalah laki-laki sebesar 79\%. Berikutnya adalah peranan aspek ekonomi a) biaya perjalanan yang berperanan menonjol adalah biaya Rp.100.000 sampai Rp.600.000 adalah sebesar $85 \%$, b) pendapatan yang berperanan menonjol adalah diatas 2 juta rupiah yaitu sebesar $50 \%$, c) jarak tempuh yang berperanan menonjol adalah kurang dari $50 \mathrm{~km}$ yaitu sebesar $44 \%$, d) waktu tempuh yang berperanan menonjol adalah lebih kurang dari 2 jam yaitu sebesar $45 \%$, e) minat kunjungan yang berperanan menonjol adalah jenis ekowisata danau yaitu sebesar $75 \%$, f) lamanya kunjungan yang berperanan menonjol adalah mereka yang berkunjung diatas 3 jam adalah sebesar $91 \%$, g) sarana dan prasarana yang berperanan menonjol adalah mereka yang menilai kondisi baik yaitu sebesar 60\%, h) frekuensi kunjungan yang berperanan menonjol adalah mereka yang berkunjung hanya satu kali yaitu sebesar 59\% serta i) motivasi kunjungan yang berperanan menonjol adalah mereka hanya memilih untuk refreshing yaitu sebesar $89 \%$.

\section{Hasil Analisis Metode Valuasi Kontingensi (Contingent Valuation Method) Analisis Persamaan Regresi Contingent Valuation Method (CVM)}

Nilai koefisien regresi Pendapatan dari hasil perhitungan SPSS adalah 0,085 hal ini menunjukkan bahwa apabila pendapatan meningkat 1\%, maka akan berpengaruh terhadap meningkatnya WTP sebesar 0,085\%. Nilai koefisien regresi Pendidikan dari hasil perhitungan SPSS adalah 0,084Hal ini menunjukkan bahwa apabila pendapatan meningkat $1 \%$, maka akan berpengaruh terhadap meningkatnya WTP sebesar $0.084 \%$. Nilai koefisien regresi Usia dari hasil perhitungan SPSS adalah 0.271, hal ini menunjukkan bahwa apabila usia meningkat $1 \%$, maka akan berpengaruh terhadap meningkatnya WTP sebesar $0.271 \%$.

Dari hasil uji t, variable yang sangat berpengaruh (signifikan) adalah variabel Usia, sementara variabel Pendapatan, Pendidikan, serta Sarana danPrasarana tidak terdapat pengaruh yang nyata. Hal ini menunjukan bahwa faktor usia sangat mempengaruhi nilai Willingness to Pay terhadap biaya tiketing dalam mendukung kelestarian lingkungan dan sumberdaya alam di kawasan Ekowisata Hulu Air Lempur, Kabupaten Kerinci

\section{Menghitung Nilai Rata-Rata Willingness To Pay (WTP)}

Nilai rerata Willingness To Pay (WTP) setiap pengunjung dihitung berdasarkan nilai penawaran WTP yang dicantumkan pada quesioner yang dipilih oleh responden. Perhitungan ini berdasarkan pada mean (nilai rerata) dari distribusi besaran WTP responden yang diambil ketika pengambilan data lapangan dilakukan terhadap 100 orang responden dari wisatawan. Adapun hasil perhitungan frekuensi besarnya pilihan responden pada nilai WTP terhadap besaran harga tiket yang ditawarkan adalah seperti Tabel dibawah ini.

Tabel 4. Distribusi Besaran WTP Pengunjung terhadap Harga Tiket Objek Ekowisata Kawasan Hulu Air Lempur Kabupaten Kerinci

\begin{tabular}{|c|c|c|c|}
\hline $\begin{array}{c}\text { Besar WTP } \\
\text { (Rp.) }\end{array}$ & $\begin{array}{c}\text { Frekuensi } \\
\text { (Orang) }\end{array}$ & $\begin{array}{c}\text { Persentase } \\
(\%)\end{array}$ & $\begin{array}{c}\text { WTP x Jumlah } \\
\text { Responden } \\
\text { (Rp.) }\end{array}$ \\
\hline 7.000 & 17 & 17 & 119.000 \\
\hline 10.000 & 35 & 35 & 350.000 \\
\hline 12.000 & 36 & 36 & 432.000 \\
\hline 15.000 & 12 & 12 & 180.000 \\
\hline & & & $\mathbf{1 . 0 8 1 . 0 0 0}$ \\
\hline Jumlah & $\mathbf{1 0 0}$ & $\mathbf{1 0 0}$ & \\
\hline
\end{tabular}


Sumber : Data Primer dan mengacu pada Hasil Pembobotan Kuesioner

Berdasarkan perhitungan data pada Tabel di atas per 100 responden dari para wisatawan maka diperoleh Nilai Rerata WTP pada Pengunjung Ekowisata Kawasan Hulu Air Lempur Kabupaten Kerinci adalah sebesar Rp.10.810 dan dibulatkan menjadi Rp 11.000,-

\section{Rancangan Strategis untuk PengembanganObjekEkowisata di Kawasan Hulu Air Lempur}

Pengembangan objekwisata alam di kawasan Hulu Air Lempur, Kabupaten Kerinci dilakukan dengan menggunakan pendekatan faktor internal (kekuatan dan kelemahan) dan eksternal (peluang dan ancaman) yang terkait dengan kondisi yang ada dilapangan. Analisis terhadapkekuatan, kelemahandanpeluang serta ancaman merupakan dasarpertimbanganyang akan.mendukung pengembangan ekowisata dimasa-masa yang akan datang (Rangkuti, F, 2005).

Adapun faktor strategis eksternal dan internal tersebut dapat dilihat pada Tabel 5.

Tabel 5. Faktor Strategis Internal dan Eksternal

\begin{tabular}{|c|c|}
\hline Internal & Eksternal \\
\hline Kekuatan & Peluang \\
\hline $\begin{array}{l}\text { - Banyaknya potensi SDA yang dimiliki kawasan } \\
\text { Hulu Air Lempur baik flora maupun fauna }\end{array}$ & $\begin{array}{l}\text { Potensi SDA dan ekowisata yang potensial untuk } \\
\text { dikembangkan dan dipromosikan }\end{array}$ \\
\hline $\begin{array}{l}\text { Terdapatlima buah ekowisata danau dan } \\
\text { panorama bukit kemulau yang sangat indah } \\
\text { dengan ciri khas masing-masing }\end{array}$ & $\begin{array}{l}\text { - Keinginan masyarakat untuk terlibat langsung dalam } \\
\text { pengembangan ekowisata }\end{array}$ \\
\hline $\begin{array}{l}\text { Ketersediaan sumber daya manusia untuk } \\
\text { mengelola dan menata kawasan ekowisata } \\
\text { adalah aset bagi kawasan ini }\end{array}$ & - Adanya sentuhan teknologiuntukpromosi ekowisata \\
\hline $\begin{array}{l}\text { Memiliki Objek Wisata Budaya, Adat Istiadat dan } \\
\text { Sejarah yang telah diagendakan untuk pesta } \\
\text { tahunan }\end{array}$ & $\begin{array}{l}\text { - Masih banyaknyapermintaanmengenai ekowisata } \\
\text { dikawasan Hulu Air Lempur }\end{array}$ \\
\hline $\begin{array}{l}\text { Pengembangankepariwisataandiakomodiroleh Para } \\
\text { tokoh adat Lekuk } 50 \text { Tumbi, pemerintah daerah } \\
\text { kabupaten dan propinsi, travel agensi serta } \\
\text { masyarakat }\end{array}$ & $\begin{array}{l}\text { Adanya keinginan untuk berkolaborasi antara pihak untuk } \\
\text { memajukan ekowisata di Kawasan Hulu Air Lempur, } \\
\text { seperti Dinas Pariwisata Kabupaten dan Propinsi, pihak } \\
\text { KP2HP dan Balai Taman Nasional Kerinci Seblat } \\
\text { (BTNKS) }\end{array}$ \\
\hline Kelemahan & Ancaman \\
\hline $\begin{array}{l}\text { - Belum dikelola secara professional seperti daerah } \\
\text { ekowisata di Pulau jawa }\end{array}$ & $\begin{array}{l}\text { - Pengembangan yang dilakukan dapat berdampak terhadap } \\
\text { rusaknya ekosistem lingkungan yang sudah terjaga } \\
\text { dengan baik }\end{array}$ \\
\hline $\begin{array}{l}\text { Kurangnya dukungan Promosi yang melibatkan } \\
\text { multi pihak terutama di even pariwisata nasional } \\
\text { maupun internasional }\end{array}$ & $\begin{array}{l}\text { Peranan masyarakat dan pihak pengelola ekowisata terus } \\
\text { ditingkatkan sejalan dengan kemajuan media informasi }\end{array}$ \\
\hline $\begin{array}{l}\text { Aksesibiitas jalan perlu dibenahi menuju desa } \\
\text { Lempur }\end{array}$ & $\begin{array}{l}\text { - Persaingan promosi wisata yang semakin ketat adalah } \\
\text { cara efektif untuk mengenalkan kawasan hulu air lempur }\end{array}$ \\
\hline - Belum melibatkan pihak investor swasta & $\begin{array}{l}\text { Pengembangan fasilitas wisata untuk kegiatan aktifitas } \\
\text { wisatawan seperti hikking, trekking dan berkemah terus } \\
\text { ditingkatkan }\end{array}$ \\
\hline $\begin{array}{l}\text { - Kurangnya dukungan anggaran dari pemerintah } \\
\text { pusat karena berhubungan dengan kawasan hutan } \\
\text { adat (kawasan konservasi) }\end{array}$ & $\begin{array}{l}\text { Potensi konflik kepentingan antara pelestarian } \\
\text { (konservasi alam/hutan) } \\
\text { - dan pemanfaatan sumberdaya alam terus diwaspadai }\end{array}$ \\
\hline
\end{tabular}

Setelah faktor-faktor strategis internal dan eksternal teridentifikasi maka dibuatlah tabel IFAS untuk merumuskan faktor-faktor strategi internal dalam kerangka Strengths dan Weaknesses serta tabel EFAS untuk merumuskan faktor-faktor strategi eksternal dalam kerangka Opportunities dan Threats.Bobot dan rating pada masing-masing faktor strategis ditentukan berdasarkan tingkat kepentingan dari faktor-faktor tersebut, setelah nilai dari masing-masing faktor ditentukan lalu dilakukan perkalian antara nilai bobot dengan nilai 
rating. Skor total bobot $\mathrm{x}$ rating pada tabel faktor strategis internal kekuatan adalah 3,10 dan skor total faktor strategis internal kelemahan adalah 2,30. Sedangkan Skor total bobot $\mathrm{x}$ rating pada tabel faktor strategis eksternal peluang adalah 3,30 dan total skor faktor strategis eksternal ancaman adalah 2,90. Untuk melihat posisi Kuadran yang mana (I, II, III, IV) maka dilakukan dicari selisih atau pengurangan antara faktor Internal (kekuatan - kelemahan), yaitu : 3,10-2,30 = 0,8, dan mengetahui faktor Eksternal (peluang - ancaman), yaitu : 3,30 $-2,90=0,4$ (Rangkuti, F, 2005)

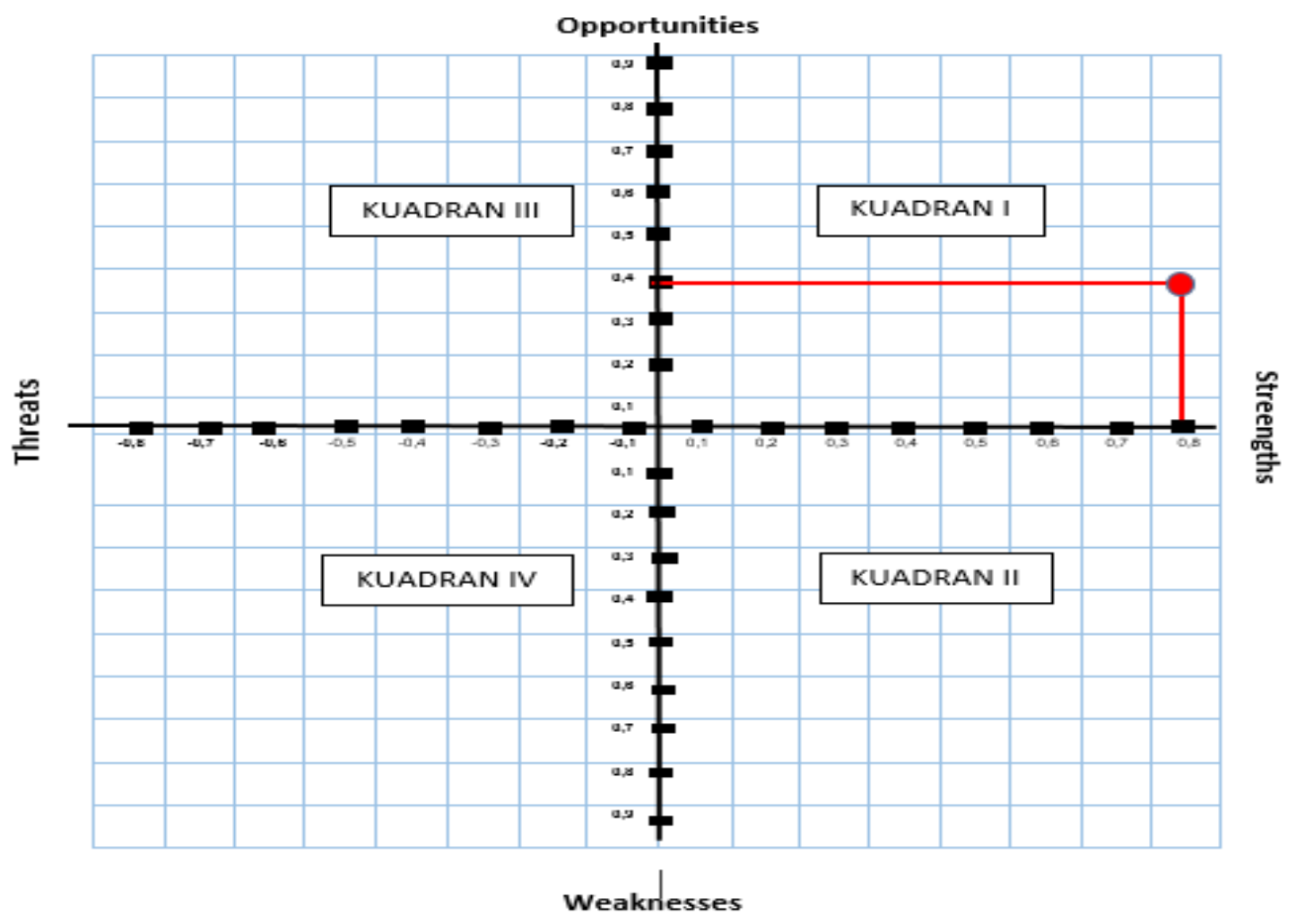

Diagram Posisi Kuadran Antara Faktor Internal dan Faktor Eksternal Hasil Analisis SWOT

\section{KESIMPULAN DAN SARAN}

Berdasarkan dari hasil penelitian dan pembahasan serta pembuktian hipotesisyang diajukan, maka dapatlah ditarik kesimpulan sebagai berikut :

1. Berdasarkan hasil skoring potensi sumberdaya alam pada objek ekowisata di Kawasan Hulu Air Lempur secara berurutan dari nilai tertinggi adalah sebagai berikut : Danau Kaco, Danau Kecik, Danau Nyalo, Danau Duo, Air Terjun Seluang Bersisik Emas, Panorama Alam Bukit Kemulau dan Danau Lingkat artinya secara berurutan sangat layak untuk dikembangkan dengan konsep ekowisata konservasi dan menjadi pilihan utama wisatawan yang ingin bertualang menjelajah alam dengan beberapa kreteria penilaian meliputi : daya tarik, aksesibilitas, lingkungan sosial ekonomi, akomodasi, sarana dan prasarana, serta ketersediaan air bersih.

2. Peranan Aspek Sosial mencakup : a) pendidikan yang berperanan menonjol adalah pada tingkat SMA dan S1, b) Usia yang berperanan menonjol adalah usia 15 sampai 26 tahun dan c) Jenis Kelamin yang berperanan menonjol adalah laki-laki. Berikutnya adalah peranan aspek ekonomi a) biaya perjalanan yang berperanan adalah biaya Rp.100.000 sampai Rp.600.000 b) pendapatan yang berperanan menonjol adalah diatas 2 juta rupiah, 
c) minat kunjungan yang berperanan adalah jenis ekowisata danau, d) sarana dan prasarana yang berperanan adalah mereka yang menilai kondisi baik.

3. Hasil analisis regresi dengan SPSS menunjukkan bahwa variabel Usia berpengaruh secara signifikan pada tarap signifikansi $5 \%$ terhadap kesediaan membayar (WTP) responden.

4. Hasil Analisis Willingness to Pay pengunjung terhadap harga tiket masuk apabila dilihat dari Metode Valuasi Kontingensi atau Contingent Valuation Method (CVM) bahwa pengunjung ekowisata Kawasan Hulu Air Lempur bersedia untuk membayar sebesar Rp. 11.000,-

5. Pada Analisis SWOT menunjukkan bahwa posisi titik potong diagram berada pada posisi kuadran I, artinya peningkatan pengelolaan ekowisata secara komprehensif, berbasiskan lingkungan harus didukung secara multisektoral terutama masyarakat setempat dengan terus meningkatkan promosi dan publikasi objek ekowisata secara nasional bahkan ketingkat Internasional.

\section{DAFTAR RUJUKAN}

Aryunda H, 2011, Dampak Ekonomi Pengembangan Kawasan Ekowisata Kepulauan Seribu Jurnal Perencanaan Wilayah Dan Kota, Vol. 22 No. 1, April 2011, Hlm.1 - 16.

Badan Perencanaan Pembangunan Daerah Tingkat II. 1993. Rancang Bangunan Restrukturisasi dan Deregulasi, Pengelolaan Sumberdaya Alam Pedesaan dan Kawasan Lindung Daerah Hulu Air Lempur Sekitarnya dan Taman Nasional Kerinci Seblat. Sungai Penuh.

Badan Perencanaan Pembangunan Nasional. 2003. Indonesia Biodiversity Strategy and Action Plan (IBSAP). The National Development Planning Agency (Bappenas).

Damanik J dan HF Weber. 2006. Perencanaan Ekowisata. Dari Teori ke Aplikasi. Pusat Studi Pariwisata (PUSPAR) UGM dan ANDI Press. Yogyakarta.

Dwyer, L. dan Edwards, D. 2000. Nature-Based Tourism on the Edge of Urban Development. Journal of Sustainable Tourism. Vol. 8(4). Hal: 267-287.

Departemen Pariwisata Republik Indonesia. 1990. Undang-Undang Republik Indonesia Nomor 9 Tahun 1990 Tentang Kepariwisataan. Jakarta.

Departemen Kehutanan Republik Indonesia. 2007. Kemungkinan Meningkatkan Ekowisata.http://www.dephut.go.id./informasi/PHPA/mphpa1.html._ Diakses Tanggal 6 September 2016.

Departemen Pariwisata Republik Indonesia. 2009. Undang-Undang Republik Indonesia Nomor 10 Tahun 2009 Tentang Kepariwisataan. Jakarta.

Dinas Pemuda Olahraga Pariwisata dan Kebudayaan Kabupaten Kerinci. 2010. Obyek dan Daya Tarik Wisata dalam Kabupaten Kerinci. Provinsi Jambi.

Direktorat Jendral Perlindungan Hutan dan Konservasi Alam. 2003. Pedoman Analisis Daerah Operasi Objek dan Daya Tarik Wisata Alam (ADO-ODTWA). Direktorat Jenderal Perlindungan Hutan dan Konservasi Alam. Bogor.

Fandeli C dan Mukhlison. 2000. Pengusaha Ekowisata. Fakultas Kehutanan UGM. Yogyakarta.

Fandeli, Chafid dan Muhammad Nurdin. 2005. Pengembangan Ekowisata Berbasis Konservasi di Taman Nasional. Fakultas Kehutanan UGM, Pusat Studi Pariwisata UGM, dan Kantor Kementerian Lingkungan Hidup. Yogyakarta.

Fauzi, A. 2010, Ekonomi Sumber Daya Alam dan Lingkungan, PT Gramedia Pustaka Utama. Jakarta

Hery Yana, 2015. Teknik Analisis SWOT, https://www.academia.edu/12941957/diakses tanggal 27 Oktober 2016. 
https://kalpataru2016.wordpress.com/2016/04/06/Lembaga Adat Lekuk 50 Tumbi Penyelamat Lingkungan - 2015, diakses 12 Nopember 2016

https://ilmugeografi.com/biogeografi/contoh-sumber-daya-alam. Di akses 3 Januari 2017.

Iqoni Nabhan, 2016. Dilema Pariwisata Kecinci. http://www.kerincitoday.com/2016/09/dilema-pariwisata-kerinci.html. Diakses pada 16 Nopember 2016.

Kahar, A, 2017. Wawancara Personal. 13 Juli 2017

Made Astawa, Ida Bagus, 2012. Potensi Sumberdaya Alam dan Pengelolaannya untuk Mendukung Kehidupan Sosial Masyarakat Adat Kawasan Gunung Batur Bangli.

Munawaroh, S, 2015. Keterkaitan Hubungan Antara Sumberdaya Alam, Sumberdaya Manusia dan Teknologi. http://sitiimunawaroh.blogspot.co.id/2015/04. Di akses pada tanggal 19 Februari 2017

Munangsihe, M. 1993. Environmental Economics and Sustainable Development. World Bank Environment Paper Number 2.

Nyoman S., 2008. Sosiologi Pariwisata, Yogyakarta : Andi Offset

Nugroho I. 2011. Ekowisata dan Pembangunan Berkelanjutan. Pustaka Pelajar. Yogyakarta.

Pajung A, S Sendji, A Arifin, A Abdullah dan Jokin AR. 1969. Tambo Adat Lekuk 50 Tumbi (Lempur). Kerinci.

Purwanto, S, 2015. Kajian Potensi Dan Model Pengembangan Ekowisata di Gunung Api Purba Nglanggeran. Skripsi, Sekolah Tinggi Pariwisata Ampta Yogyakarta. Yogyakarta

Rangkuti, F. 2005. Analisis SWOT Teknik Membedah Kasus Bisnis, PT. Gramedia Pustaka Utama, Jakarta.

Romani S. 2006. Penilaian Potensi dan Daya Tarik Wisata Alam Serta Alternatif Perencanaannya di Taman Nasional Bukit Dua Belas Provinsi Jambi. Skripsi. Departemen Konservasi Sumberdaya Hutan dan Ekowisata.Fakultas Kehutanan. Institut Pertanian Bogor. Bogor.

Sachs, JD, and Warner, AM,1997. Sources of Slow Growth in African Economies, Institute for International Development and Center for International Development Harvard University. Published in Journal of African Economies, December 1997, Volume 6, Number 3, pp. 335-376Sitohang, S.

Soemarwoto, O. 1997. Ekologi, Lingkungan Hidup dan Pembangunan. Cetakan Ketujuh (Edisi Revisi). Penerbit Djambatan. Jakarta.

The Ecotourism Society. 1990, dalam Fandeli, C, Et Al. 2000. Pengusahaan Ekowisata. Yogyakarta: Fahutan UGM - UKSDA DIY - Pustaka Pelajar

The Ecotourism Society (TES), 1995, Ekoturisme: Petunjuk untuk Perencana dan Pengelola (in Bahasa Indonesia), Jakarta: Private Agencies Collaborating Together (PACT) and Yayasan Alam Mitra Indonesia (ALAMI), in Bahasa Indonesia. 